\title{
Zdeněk Fibich's Piano Works from the Performer's Position
}

\author{
Tomáš Víšek
}

Perhaps many of us who know Fibich's music will agree that Fibich's piano works, although one of the dominant areas among his compositions (and one which the composer invests with a very deep feeling and intimacy), are performed and presented very rarely. Is it just unfair play, or does it have any deeper reasons? This article tries to discover the problems-not from the musicological or sociological aspect, but from the practical interpreter's view (hardly articulated at all until recently).

Fibich's piano works can be divided into 3 basic areas, each with a slightly different problem to appreciate fully. In this paper I explore the first two areas briefly (but omit the 4-hand pieces). Early opus numbers arose mostly when Fibich was aged 15-16; here he is of course just learning to compose and he is under the influence of great examples like Mendelssohn (his lyrically animated Le printemps, Op. 1), Smetana (the first and last pieces from Feuillets d'Album, Op. 2) and especially Schumann. But most of the works from this period show an indubitable talent and good potential, primarily the pieces with a lyrical character (the fast pieces from Op. 2 are conceived rather mechanically, one of them being almost a copy of Schumann's Fantastic Dance in e minor). The highest artistic position is reached by the Dvě scherza [Two Scherzos], Op. 4, although inspired by Schumann's Kreisleriana (1.) or Dvořák (2.), especially the first one, which is solid in structure, has an attractive, jocular mood and is easily playable. These scherzos should be presented more often in concert-but the other compositions are usable too at the formative stage of study. Of course, all these pieces should be recorded as well (there is as yet no CD. Velká teoreticko-praktická klavirní škola [The Big Theoretic-Practical School for Piano] (authors Z. Fibich and J. Malát, 1884-1885, total 5 parts, i.e. 30 books) is clearly out of date in its methodology; progress here while systematic is also very slow. So looking for attractive compositions is sometimes similar to trekking through the jungle. But some selections from parts 1-3 have been released: "Exercises and Etudes" (compiled by L. Láska), “Album II.” (Růžena Kurzová) and "For Children” (Věra Koubková). Thanks to these albums, we can register almost everything significant from the first two parts and most from the $3^{\text {rd }}$ part-here the editors completed the pieces pragmatically, by phrasing 
(Fibich had only supplied markings in half of the $2^{\text {nd }}$ part), pedal indications (Fibich only marked pedalling from the end of the 4th part!) etc. (On the contrary, dynamic levels are clearly indicated by Fibich himself.) I personally would not hesitate to demonstrate several pieces to a pupil for selection. I think everybody will find something lovely and attractive in the music. It is just a pity that the endeavour to project unified albums "drowned" almost all compositions which featured scales (as well as the most logical and comfortable fingering for them); there are absolutely no academic pieces (thanks to the use of various rhythms, clever polyphonic textures or telling melodies). Also several other lovely pieces from this part were not included. But parts 4-5 (mainly etudes) were not selected at all; part 4 does not exceed Czerny, but the etudes from the last part have a concert character like pieces by Moscheles, Chopin or Liszt. Apart from their geniality, they are rewarding and effective and would be nice as encores or recordings. (Pieces from this school have not been recorded at all.)

Now to the three top opus numbers-the cycles $Z$ hor [From the Mountains], Op. 29, Nálady, dojmy a upomínky [Moods, Impressions and Reminiscences] (the biggest piano cycle in the world-376 finished and published compositions!) and Malírské studie [Studies of Painters], Op. 56 (the last definitive piece of Fibich's to be completed). Without doubt, they are the most significant of Fibich's piano works. On the other hand, he in no way simplified the role of the pianist. He often demands large, even enormous dimensions of the hands, his pianistic style is often needlessly complicated, impractical, with ineffectual thick chords, very difficult to co-ordinate, not always in well- sounding positions, sometimes resulting in what seems like unrealized orchestral sketches. It is almost as if Fibich did not play any more (in his youth he wanted to became a concert pianist!) in this period of his life, or just "for amusement". (By the way, I performed and recorded on Fibich's instrument from this era-it is a rather average, small and not too well-sounding "Alois Schreiber" grand piano, and every attempt at a dramatic expression makes for a very poor sound and risks destroying the instrument.) Of course this uncomfortable style is especially complicated for a pianist with small hands (it is often impossible to seize or hold big chords or various sustained tones, they have to be executed by arpeggios, compromised by the sustaining pedal etc.), but all have to solve the basic problems of the music in its entirety, respecting all of the author's instructions (often very detailed), although only the gripping of some chords can be very draining. In this case, it is better to concentrate on the musical stream and outward appearance-the omission of some tones inside the chord is better than a permanent tense struggle and the overall sound of the composition is almost never damaged. (Typical for example, are parts 1, 2 and 4 from Malírské studie, but also plenty of pieces from Nálady, dojmy a upomínky, including the famous Poème No. 139, No. 1 etc.) Besides, some pieces are patently impractical (a.o. Nos. 101, 352), although they are more playable by dividing the hands. Sometimes we can change the phrasing (for example, the last period of No. 263, in the manner of a furiant-the fundamental nonstop-legato is really very difficult), while No. 268 (with a "Spanish" mood) is an example where the result does not sound convincing. Even a lot of pieces are not easily playable "by themselves": it means that they look rather grey, con- 
trived, boring, harmonically or formally crude when we simply play them superficially. Of course this impression can be discouraging. But they suddenly breathe life and become colourful, if we observe the details precisely, or if we dive into wide-breathing phrases or simply into the inspiration of love or nature. (Not only in the "biggest cycle"-also in part I. or II./2, and part of II./ 6 in $Z$ hor etc.) Of course, we do not have to study the books by Zdeněk Nejedlý (Zdeňka Fibicha milostný deník [Zdeněk Fibich's Love-Diary]) or the monograph by Jaroslav Jiránek in detail (although they are very useful and attractive, as is the polemic brochure by Jarmil Burghauser, Nejen pomníky [Not Only Monuments]). It is not necessary to be informed in absolute detail about the interpretation, it is enough to be generally informed and aware of all the details and points. Otherwise, the compositions will not prove attractive.

From these three cycles, the cycle $Z$ hor (1887), inspired by Liszt's Années de pelerinage in the first part ( $1^{\text {st }}$ piece) and by the vividly dancing Schumann or even more by Brahms's Intermezzos in the second part (6 shorter pieces), is the most compact and least complicated. Here Fibich shows the inspiration of citations from the poetry of J. Vrchlický, Noc v kláštere [Night in the Monastery], or Cesta do Alp [Journey in the Alps] in front of every piece. It might be useful to present the first words of these mottos next to the tempo markings in printed programmes, as it could make this cycle more attractive. Of course, nobody expects a complete performance of the cycle Nálady, dojmy a upomínky (1892-1899); only Marian Lapšanský made a complete CD recording for Supraphon and Milan Balcar performed this cycle within 8 evenings during the "first republic". It is also clear that not all pieces (given the quantity of the collection!) are of the same level; they are sometimes conceived very quickly (Fibich disliked tedious refining!) and sometimes repeat themselves. (Somewhat similar is the situation with Mendelssohn and his Songs without Words.) But we are always able to prepare a representative and varied selection for 20-30 minutes, and if we do not want to search "piece-by-piece" through the work, we can use some compilations assembled by others. On a basic level we can use Jiránek's compilation Milostný deník Zdeňka Fibicha [The Love-Diary of Zdeněk Fibich] (containing most of the various moods and styles and also with a generous foreword, if only in the Czech language. By the way, we have almost no available texts for foreigners, except resumées in some books, sleevenotes to CDs and some forewords to other compositions. This is also a topic for future discussion). The other compilations, Album I. (edited by by J. Heřman) and especially Album (edited by Fr. J. Khodl), are much more unified (especially the second one), although we can find here some nice pieces for completing a program. It might also be worthwhile to organize a competition for the interpretation of these pieces or selections from them (at least in the jubilee years ending in 5 or 0 -pianists would then recognize these pieces and some of them would keep them in their repertoire).

The most complicated situation is undoubtedly with the last cycle Malírské studie (1899), inspired by Liszt. Of course it is not the first such Liszt-inspired piece (next to $Z$ hor part I., for example No. 368 from the previous cycle, in the style of the etude Wilde Jagd, but weakened by an uneven and unconvincing style). But here Liszt's example, the first of all the Années de pelerinage, is wholly authoritative. Concerning the lyrics (intimate 
as well as dramatic), Fibich is equal to Liszt, but his solving of technical problems and rhythmic-technical issues is much less grateful and effective, and those places discribing the epic or quick movement are suddenly perfunctory and stiff. (A similar comment might be made about Schumann's vocal works.) If concerning just an episode (the central "hunters" in No. 1, Lesní samota [A Silvan Solitude]), the outside parts will compensate for it. The worst situation arises if these elements go through the whole piece, as in No. 2, Spor masopustu s postem [The Dispute between Shrove Tuesday Carnival and Lent]. In many places, each hand has to be both soloist as well as accompanist by itself; if the left hand is accompanying, it sometimes has to execute very uncomfortable and ineffective leaps. The above-mentioned overcrowded texture and over-stretching of the hands (while asking for a clear, prominent melody or ornaments at the same moment, a device sometimes used in the previous cycle, too) are here sometimes beyond the bounds of playability, so conveying the real carnival mood and fire is extremly difficult. On the contrary, the serious, clerical theme of lent, which sometimes disrupts this flow, is only several bars long, in other words just a naive motive, mechanically repeated, including the end with its victory. The $3^{\text {rd }}$ piece Rej blažených [The Dance of the Happy Ones] is also spiritual, very devout and with very detailed directions for dynamics and phrasing. The serious interpreter has to put all the details "into his or her blood" and then to concentrate solely on the momentum, in order not to break the natural breath of the music. (The last bar of this piece is unclear; in 6/4 meter there is a chord in square notes, actually a breve with a dot. But it can also be a standard mistake, indicating a "mute chord", sounding just after the pedal change.) Piece No. 4 Jo a Jupiter [Jo and Jupiter] is a more compact analogy of piece 1, but also longer, and the main theme is repeated many times, so it is also exacting for performers to keep the attention of the listeners here. Of course we have a contrast after these two lyrical pieces, but in an absolutely unexpected form. No more Liszt, but the title Zahradni slavnost [A Garden Party] is made-up as a "Tafelmusik" in the strict style of a baroque suite in 5 parts (really, a "composition within a composition") but with the intrinsically Romantic dynamics of permanent crescendos and decrescendos. The middle dance often has almost unrealistic leaps (of an eleventh!), the motives are not too expressive (throughout the piece) and every dance is a little longer than the previous one (especially the last, twice as long), except for a modest reminiscence of the beginning of this "dance suite" at the very end). So, the whole impression from this cycle is a bit incongruous (first of all because of numbers 2 and 5) and the interpretation of the whole cycle calls for considerable effort, more than with the major Romantics. In spite of this, thanks especially to the strong lyricism of Fibich, we have to recognize it as a very interesting and significant cycle and we should play and advertise it more often (it is an obligation for us Czechs), as well as many others of Fibich's piano works. Just a thought: if we were Americans, we would surely manage to include the Nálady, dojmy a upomínky into the Guinness Book of Records and perhaps we would build a Hollywood love story from Fibich's fate in love, with proper piano pieces in the background, later released in the form of a soundtrack, with a massive advertisement campaign etc. etc. But I realise that I am finishing on an absolutely utopian note! 


\title{
Fibichs Klavierwerke aus dem Standpunkt des Interpreten
}

\author{
Zusammenfassung
}

Klavierwerke von Fibich kann man in 3 grundlegende Bereiche, die jeweils mit einem etwas anderen Problem der Schätzung aufgeteilt werden. Frühwerke sind natürlich im Rahmen eines großen Einfluss wie Mendelssohn (Op. 1), Smetana (erste und letzte Teil des Op. 2) und Schumann im Besonderen. Die beste und umfassendste förmlich sind 2 Scherzos, Op. 4. Eine große theoretische und praktische Schule (Z. Fibich, J. Malát, 5 Teile, insgesamt 30 Hefte), schon völlig veraltet in der Methodik, enthält viele wertvolle Stücke für Kinder, manchmal von Redaktoren in verschiedenen Alben formiert (siehe vollständige tschechische Text), der letzte Teil umfasst viele Konzert-Etüden (kein Genie Chopin, Liszt, usw., aber dankbar und manchmal spektakulär als die potenziellen Zugaben oder Tonaufnahmen). Drei Höchstklavierzyklen sind nicht nur die wichtigsten, sondern auch die umstrittensten. In der lyrischen Stimmung kann man als Vorbild gelten (Schumann, Liszt, Chopin usw.), in der Technik erfordert man häufig abnormale Spannweite von Hand, Klavierabfassen ist unnötig kompliziert und unpraktisch, dichte Akkorden, sehr schwierig für Legato, außerdem gelegentlich schlecht klingende Position. Der Zyklus Aus den Bergen, Op. 29 ist das kompakteste und am wenigsten kompliziert. Stimmungen, Eindrücke und Erinnerungen (der weltweit größte Klavierzyklus, 376 vollendete Kompositionen!) ist gut als eine repräsentative Stichprobe zu spielen (20-30 minuten), wurde ebenfalls veröffentlicht mehrere Kompilationen (die beste von J. Jiránek). Die größte Diskrepanz liegt im letzten vollendeten Werk Fibichs überhaupt, Malerstudien, Op. 56 - Nr. 1, 3 und 4 sind sehr effektiv bei der Lyrik, Nr. 2 ist Anhäufung der sehr anspruchsvollen, manchmal unspielbaren und uneffektiven technischen Elemente und der schematischen Form, letzte Nr. 5 ist unerwartet in Form einer barocken Tanzsuite (wörtlich „Zyklus im Zyklus“), so der Gesamteindruck ist etwa verschiedenartig. Doch alle diese Zyklen sind sehr beachtenswert, vor allem dank der Lyrik, und verdient, öfter zu spielen.

\section{Klavírní dílo Zdeňka Fibicha z pozice interpreta}

\section{Shrnutí}

Fibichovo klavírní dílo můžeme rozdělit do tři základních oblastí, každé s poněkud jiným problémem docenitelnosti. Rané opusy jsou pochopitelně pod velkým vlivem např. Mendelssohna (Op. 1), Smetany (první a poslední část Op. 2) a zejména Schumanna. Nejlepší a formálně nejucelenější jsou 2 Scherza, Op. 4. Velká teoreticko-praktická škola (Z. Fibich, J. Malát, 5 dílů, 30 sešitů), již zcela zastaralá v metodice, obsahuje mnoho cenných skladeb pro děti, občas různými editory sestavených do alb, poslední část obsahuje koncertní etudy (bez geniality Chopina, Liszta apod., ale vděčné a občas efektní jako potenciální přídavky či nahrávky). Tři vrcholné klavírní cykly jsou nejvýznamnější, ale také nejrozporuplnější. V lyrické náladě se naprosto vyrovnají velkým vzorům (Schumann, 
Liszt, Chopin atd.), v technice často vyžadují abnormální rozpětí ruky, klavírní stylizace je zbytečně komplikovaná a nepraktická, se zbytečně hustými akordy, velmi nesnadnými pro legato, navíc občas v nedobře znějící poloze. $Z$ hor, Op. 29 je nejkompaktnější a nejméně komplikované. Nálady, dojmy a upomínky (největši klavírní cyklus světa, 376 dokončených skladeb!) je dobré hrát jako reprezentativní výběr (20-30 minut), vyšlo též několik kompilací (nejlepší od J. Jiránka). Největší rozpor je v Malǐrských studiích, Op. 56 - č. 1, 3 a 4 jsou velmi účinné v lyrismu, č. 2 je kumulací velmi náročných, občas nehratelných a neúčinných technických elementů a schematické formy, poslední č. 5 je nečekaně ve formě barokní taneční suity, celkový dojem je tedy poněkud nesourodý. Přesto jsou všechny tyto cykly velmi pozoruhodné, hlavně svou lyrikou, a zasloužily by častější uvádění.

\section{Keywords}

Zdeněk Fibich's piano music; interpretation. 